\title{
Simulasi waduk Margatiga di Kabupaten Lampung Timur
}

\author{
Triyanto $^{\text {a, }}$, Endro Prasetyo Wahono ${ }^{\text {b }}$, Dyah Indriana Kusumastutic \\ a Mahasiswa Program Studi S2 Teknik Sipil, Universitas Lampung, Jl. Soemantri Brojonegoro No. 1 Bandar Lampung, 35145, Indonesia \\ ${ }^{b}$ Jurusan Teknik Sipil, Universitas Lampung, Jl. Soemantri Brojonegoro No. 1 Bandar Lampung, 35145, Indonesia \\ c Jurusan Teknik Sipil, Universitas Lampung, Jl. Soemantri Brojonegoro No. 1 Bandar Lampung, 35145, Indonesia
}

\section{H I G H L I G H T S}

- Kondisi pasokan air, terutama untuk sumber daya air tawar di masa depan sulit untuk dinilai karena berbagai faktor alam yang tidak pasti dan berubah.

- Perubahan iklim akan mempercepat siklus air dan karenanya sumber daya air tawar mungkin akan terbatas di masa depan sehingga risiko masalah terkait air akan tetap ada di masa yang akan datang karena perubahan pola musim dan peningkatan kejadian ekstrem.

\section{N F O ART I KEL}

Riwayat artikel:

Diterima 11 April 2020

Diterima setelah diperbaiki 7 Juli 2020

Diterima untuk diterbitkan 21Agustus 2020

Tersedia secara online 01 Desember 2020

\section{Kata kunci:}

Simulasi waduk,

tingkat keandalan waduk,

waduk Margatiga.

\begin{abstract}
A B S T R A K
Tujuan penelitian ini adalah melakukan simulasi waduk Margatiga di Kabupaten Lampug Timur dengan adanya inflow dan outflow selama periode tiap pertengahan bulan dalam setahun dalam rangka melihat keandalan waduk Margatiga tersebut. Dalam penelitian ini dilakukan analisis inflow, outflow dan water balance dari data nyata pengamatan terukur. Analisis inflow menggunakan data limpasan debit Bendung Argoguruh periode tahun 2002 - 2019 dan analisis debit DAS Waduk Margatiga dari data PDA 124 di Desa Negri Jumanten periode tahun 2002 - 2009. Analisis outflow meliputi evaporasi, kebutuhan air irigasi di jaringan irigasi Jabung, pemeliharaan lingkungan hilir dan penyediaan air baku potensial. Analisis water balance digunakan untuk mengetahui volume tampungan waduk akibat inflow dan outflow. Selanjutnya dilakukan simulasi waduk dengan tiga skenario. Simulasi 1 untuk mengaliri kebutuhan irigasi di intake kiri Bendung Jabung (sawah) 5.638 ha, simulasi 2 untuk mengaliri kebutuhan intake kanan bendung Jabung (sawah) 10.959 ha dan Simulasi 3 untuk mengaliri kebutuhan irigasi kiri dan kanan ditambah menyedia-kan air baku 0,8 $\mathrm{m}^{3} /$ detik. Hasil penelitian menunjukkan bahwa inflow waduk yaitu limpasan bendung Argoguruh dan debit terukur DAS waduk mempunyai pola yang sama dalam periode setahun. Hasil perhitungan outflow menunjukkan grafik ketiga skenario mempunyai pola yang sama dalam periode setahun. Selain itu, hasil keandalan simulasi 1 adalah 100 $\%$, simulasi 2 adalah 85,0 \% dan simulasi 3 adalah 70,8\%.
\end{abstract}

Diterbitkan oleh Jurusan Teknik Sipil Universitas Lampung

\section{Pendahuluan}

Meningkatnya permintaan air untuk industri, mensuplai kebutuhan di kota dan pertanian telah meningkatkan kebutuhan akan konstruksi bendungan [1]. Salah satu prioritas pemerintah Indonesia dalam rangka menjaga ketahanan pangan dan meningkatkan kese-jahteraan masyarakat adalah dengan melakukan pengem-bangan sumber daya air, yaitu melakukan optimalisasi sumber daya air dengan cara membangun infrastruktur sumber daya air berupa bendungan. Keseriusan pemerintah dituangkan dalam Nawa Cita program ketahanan pangan dan air lewat Kementrian Pekerjaan Umum dan Perumahan Rakyat (PUPR)

* Penulis koresponden.

Alamat e-mail: triyantot129@gmail.com (Triyanto)

Peer review dibawah tanggung-jawab Jurusan Teknik Sipil

Universitas Lampung.

https://doi.org/10.23960/rekrjits.v24i3.43 yang menargetkan pembangunan 65 bendungan dalam periode 2015 - 2019.

Bendungan Margatiga yang berada di Desa Negeri Jumanten, Kecamatan Margatiga, Kabupaten Lampung Timur merupakan salah satu bendungan yang sedang dalam proses pembangunan. Pembangunan bendungan Margatiga merupakan satu kesatuan pemanfaatan air sungai Way Sekampung dari hulu hingga hilir sungai yang bersifat cascade. Cascade adalah bangunan bendungan dibuat bertingkat atau berseri (untuk keperluan yang sangat vital misalnya untuk irigasi [2, 3] di sejumlah lokasi dari hulu ke hilir sepanjang aliran sungai Way Sekampung. Di sepanjang aliran sungai Way Sekampung, di bagian paling hulu terdapat Bendungan Batutegi, pada bagian tengah terdapat Bendungan Way Sekampung dan di bagian hilir Bendungan Margatiga. Pada umumnya, bendungan yang dibangun memiliki banyak fungsi [4-6] dan fungsi utama Bendungan Margatiga adalah untuk keperluan irigasi Bendung Jabung, 
yang berada di hilir waduk berjarak $\pm 60,00 \mathrm{~km}$ dari Bendungan Margatiga, selain digunakan juga untuk pengendalian banjir, penyediaan air baku air minum, pariwisata dan pemeliharaan lingkungan di daerah hilirnya. Waduk Margatiga memiliki kapasitas tampungan normal $29,92 \times 10^{6} \mathrm{~m}^{3}$, yang akan memberikan pasokan air irigasi di irigasi Bendung Jabung, potensial penyediaan air baku dan pemeliharaan lingkungan di daerah hilir.

Secara khusus, bendungan memiliki dampak besar pada hidrologi sungai, terutama melalui perubahan waktu, besaran dan frekuensi aliran tinggi dan rendah, yang pada akhirnya menghasilkan rezim hidrologi yang berbeda secara signifikan dari kondisi alami sebelum adanya bendungan [7-9]. Selain itu, Lee $d k k$. [10] juga menjelaskan manfaat lain dari penggunaan model simulasi adalah untuk mensimulasikan aliran sungai meliputi penggunaan seri data yang lebih panjang untuk analisis frekuensi, mensimulasikan aliran sungai di bawah kondisi penggunaan lahan/iklim di masa depan, dan transformasi langsung dari curah hujan desain untuk banjir desain. Oleh sebab itu, tujuan penelitian ini adalah melakukan simulasi waduk Margatiga di Kabupaten Lampug Timur dengan adanya inflow dan outflow selama periode tiap pertengahan bulan dalam setahun dalam rangka melihat keandalan waduk Margatiga tersebut.

\section{Metode Penelitian}

Secara geografis, bendungan Margatiga berada pada $105^{\circ} 26^{\prime} 26^{\prime \prime}$ LS dan secara administratif berada di wilayah Desa Negeri Jumanten, Kecamatan Margatiga Kabupaten Lampung Timur. Data yang digunakan berasal dari beberapa instansi, sebagai berikut: peta Topografi, peta daerah aliran sungani (DAS), debit limpasan dari Bendung Argoguruh periode 2002-2019, data pengukuran debit sesaat di lokasi sungai Way Sekampung daerah PDA 124 Desa Negri Jumanten, data pengambilan tinggi muka air (TMA) di pos pengamatan PDA 124 Desa Negri Jumanten periode 2002-2009, data Klimatologi dari stasiun maritim Panjang Lampung Selatan dan data kebutuhan air untuk irigasi DI Rawa Sragi Jabung Lampung Timur. Daerah tangkapan hujan atau daerah aliran sungai (DAS) yang bermuara pada bendungan Margatiga merupakan DAS yang berhulu pada bendung Argoguruh di Tegineneng, kabupaten Lampung Selatan. DAS tersebut mempunyai luas $254,97 \mathrm{~km}^{2}$ dengan panjang sungai utama (sungai Way Sekampung) 50,26 km. Secara hidrologis, DAS ini dipengaruhi oleh beberapa stasiun hidrologi atau stasiun hujan yaitu R-142 (Stasiun Margatiga /Sukadana) di Kabupaten Lampung Timur, PH-103 (Stasiun Bendung VIII Punggur) di Kabupaten Lampung Tengah, PH-034 (Stasiun Sidosari) di Kabupaten Lampung Selatan.

Analisis inflow dilakukan dengan menganalisis debit limpasan bendung Argoguruh periode 2002-2019 dan menganalisis debit terukur DAS waduk Margatiga dari data PDA 124 periode 2002-2009 serta pengukuran debit sesaat di lokasi PDA 124. Analisis data debit limpasan harian Bendung Argoguruh periode 2002 - 2019 menjadi data rata-rata debit setengah bulanan dalam tahunan. Analisis data debit sesaat dalam rating curve untuk menghitung debit air sungai periode 2002 - 2019 dan menjadi data debit rata-rata setengah bulanan dalam tahunan.

Kemudian outflow merupakan semua parameter yang harus disuplai atau disediakan airnya oleh waduk Margatiga.
Pengumpulan data debit outflow dilakukan di dua tempat yaitu di bendung Jabung dan di lokasi bendungan Margatiga. Analisis outflow adalah menganalisis besarnya evaporasi, penggunaan kebutuhan air lingkungan hilir, penggunaan air untuk irigasi Jabung kiri dan irigasi Jabung kanan serta penyediaan air baku. Data debit ouflow di bendung Jabung yaitu data perencanaan kebutuhan air untuk pengairan ke jaringan Irigasi Jabung kanan dan kiri sesuai RTTG gubernur Lampung. Data di bendungan Margatiga adalah data pengukuran klimatologi untuk perhitungan evaporasi dan data asumsi penggunaan air baku potensial $0,8 \mathrm{~m}^{3} /$ detik. Selain itu juga menganalisis data debit kebutuhan air di jaringan Irigasi Jabung menjadi kebutuhan debit air tiap setengah bulanan dalam tahunan dan menganalisis data klimatologi dari stasiun Kalianda menjadi perhitungan evaporasi dalam setengah bulanan dalam tahunan. Selanjutnya, menganalisis debit penggunaan air baku dalam rata-rata setengah bulan dalam tahunan dan debit rata-rata bulanan untuk kebutuhan lingkunan hilir. Persamaan tampungan waduk disajikan seperti pada Persamaan 1 [11]

$S_{t+1}=S_{t}+I-O$

dengan $S_{t+1}$ adalah tampungan pada periode $t, t$ adalah interpal waktu yang digunakan, $S_{t}$ adalah tampungan awal pada periode $t, I$ adalah total volume debit inflow yang masuk ke waduk selama periode $t$ dan $O$ adalah total volume debit outflow yang keluar dari waduk selama periode $t$.

Secara umum, prosedur pelaksanaan penelitian ini sebagai berikut. Simulasi waduk, berdasarkan komponen inflow dan outflow di atas, maka neraca air di waduk Margatiga dapat diformulasikan seperti Persamaan 2.

$\Delta S=I_{1}+I_{2}-O_{1}-O_{2}-O_{3}-O_{4}-O_{5}$

dengan $\Delta S$ adalah volume tampung waduk (juta $\mathrm{m}^{3}$ ), $I_{1}$ adalah volume inflow limpasan Bendung Argoguruh (juta $\mathrm{m}^{3}$ ), $I_{2}$ adalah volume inflow debit DAS waduk Margatiga (juta $\mathrm{m}^{3}$ ), $O_{1}$ adalah volume outflow evaporasi waduk Margatiga (juta $\left.\mathrm{m}^{3}\right), O_{2}$ adalah volume outflow irigasi Jabung kanan (juta $\mathrm{m}^{3}$ ), $O_{3}$ adalah volume outflow irigasi Jabung kiri (juta $\left.\mathrm{m}^{3}\right), O_{4}$ adalah volume outflow pemeliharaan hilir (juta $\mathrm{m}^{3}$ ) dan $O_{5}$ adalah volume outflow pemakaian air baku (juta $\mathrm{m}^{3}$ )

Adapun data yang dianalisis untuk melihat volume evaporasi adalah data dari stasiun meteorologi maritim Panjang, Bandar Lampung selama tahun 2019 dengan perhitungan menggunakan metode Penman. Lalu, untuk kebutuhan air irigasi Jabung di pintu intake kanan Bendung Jabung (10.959 ha) sesuai data perhitungan perencanaan dari sumber Balai Besar Wilayah Mesuji Sekampung dan untuk kebutuhan air Irigasi Jabung di pintu intake kiri bendung Jabung (5.638) juga sesuai dengan data perhitungan perencanaan dari sumber Balai Besar Wilayah Mesuji Sekampung. Selanjutnya, untuk kebutuhan pemeliharaan lingkungan air di hilir (MF) waduk, kebutuhan air diasumsikan 2,00 $\mathrm{m}^{3} /$ detik. Data ini didapat dari Review Design bendungan Margatiga. Debit ini rutin tiap hari dialirkan ke hilir karena untuk penggunaan komunitas ekosistem di bagian hilir. Terakhir adalah kebutuhan air baku potensial $0,80 \mathrm{~m}^{3} / \mathrm{s}$. Untuk kebutuhan air baku dengan korversi menjadi satuan volume kebutuhan air dengan cara dikalikan jumlah hari pada pertengahan bulan dikalikan 24 jam x 60 menit x 60 detik.

Kemudian, dilakukan tiga skenario simulasi sebagai berikut. Skenario 1 adalah $\Delta S=I_{1}+I_{2}-O_{1}-O_{2}-O_{3}$, skenario 2 adalah $\Delta S=I_{1}+I_{2}-O_{1}-O_{2}-O_{3}-O_{4}$ dan skenario 3 adalah $\Delta S=I_{1}+I_{2}-O_{1}-O_{2}-O_{3}-O_{4}-O_{5}$. Simulasi 1 dilakukan 
untuk pengaliran irigasi Jabung kanan seluas 5.638,00 ha, yang saat ini jaringan irigasi sudah proses pekerjaan, sedangkan simulasi 2 untuk kebutuhan irigasi Jabung kanan dan kiri yang saat ini memiliki lahan potensial sebesar $10.959,00$ ha dan simulasi 3 untuk pengaliran irigasi Jabung kanan dan kiri beserta pelayanan untuk kebutuhan air baku di Lampung Timur berkapasitas potensial 0,80 $\mathrm{m}^{3} /$ detik.

Kemudian dilakukan juga perhitungan tingkat kehandalan waduk, yang berfungsi untuk mengukur kemampuan waduk dalam memenuhi fungsinya yaitu memenuhi kebutuhan target pelepasan waduk. Keandalan ketiga simulasi tersebut di atas dihitung menggunakan Persamaan 3.

$$
R=\frac{n}{N}
$$

dengan $\mathrm{R}$ adalah tingkat keandalan waduk (\%), $\mathrm{N}$ adalah panjang data periode waktu setengah bulanan, dan $\mathrm{n}$ adalah jumlah kegagalan operasi waduk selama periode setengah bulanan.

\section{Hasil dan Pembahasan}

Luas tangkapan hujan waduk Margatiga sampai dengan bagian bangunan di hulu (bendung Argoguruh) adalah $255,00 \mathrm{~km}^{2}$. Kondisi saat ini inflow waduk Margatiga berasal dari limpasan bendung Argoguruh dan limpasan area tangkapan hujan di waduk Margatiga. Di lokasi waduk terdapat pos pengamatan Papan Duga Air (PDA 124) digunakan untuk pengukuran debit sungai di area waduk. debit inflow di Waduk Margatiga diperoleh dengan penggabungan antara debit limpasan dan debit terukur di sungai lokasi waduk. Perhitungan inflow total disajikan pada Tabel 1 dan diilustrasikan seperti pada Gambar 1 . Selanjutnya, pemanfaatan utama waduk adalah untuk pengairan irigasi, penyediaan air baku, pengairan lingkungan hilir dan sebagian ditampungan waduk terjadi proses evaporasi. Hasil perhitungan outflow total dalam tiga skenario simulasi disajikan pada Tabel 2 dan diilustrasikan pada Gambar 2 - Gambar 4. Selanjutnya, volume tampung waduk dalam tiga skenario simulasi disajikan pada Tabel 3 - Tabel 5 dan elevasi muka air waduk diilustrasikan pada Gambar 5- Gambar 7.

Tabel 1

Volume inflow waduk Margatiga

\begin{tabular}{llll}
\hline Periode & $\begin{array}{l}\text { Limpasan, } I_{1} \\
\left(\mathrm{~m}^{3}\right)\end{array}$ & $\begin{array}{l}\text { DAS waduk, } I_{2} \\
\left(\mathrm{~m}^{3}\right)\end{array}$ & $\begin{array}{l}\text { Total } \\
\left(\mathrm{m}^{3}\right)\end{array}$ \\
\hline Januari-1 & $66,88 \times 10^{6}$ & $34,39 \times 10^{6}$ & $101,27 \times 10^{6}$ \\
Januari-2 & $80,50 \times 10^{6}$ & $47,25 \times 10^{6}$ & $127,75 \times 10^{6}$ \\
Februari-1 & $67,78 \times 10^{6}$ & $27,30 \times 10^{6}$ & $95,08 \times 10^{6}$ \\
Februari-2 & $83,88 \times 10^{6}$ & $25,26 \times 10^{6}$ & $109,14 \times 10^{6}$ \\
Maret-1 & $88,15 \times 10^{6}$ & $52,25 \times 10^{6}$ & $140,40 \times 10^{6}$ \\
Maret-2 & $51,80 \times 10^{6}$ & $46,96 \times 10^{6}$ & $51,80 \times 10^{6}$ \\
April-1 & $61,68 \times 10^{6}$ & $24,25 \times 10^{6}$ & $98,76 \times 10^{6}$ \\
April-2 & $15,29 \times 10^{6}$ & $19,44 \times 10^{6}$ & $34,73 \times 10^{6}$ \\
Mei-1 & $19,63 \times 10^{6}$ & $6,23 \times 10^{6}$ & $25,86 \times 10^{6}$ \\
Mei-2 & $11,98 \times 10^{6}$ & $6,04 \times 10^{6}$ & $18,02 \times 10^{6}$ \\
Juni-1 & $1,43 \times 10^{6}$ & $4,53 \times 10^{6}$ & $5,96 \times 10^{6}$ \\
Juni-2 & $4,38 \times 10^{6}$ & $4,09 \times 10^{6}$ & $8,47 \times 10^{6}$ \\
Juli-1 & $4,60 \times 10^{6}$ & $4,43 \times 10^{6}$ & $9,03 \times 10^{6}$ \\
Juli-2 & $15,53 \times 10^{6}$ & $4,45 \times 10^{6}$ & $19,98 \times 10^{6}$ \\
Agustus-1 & $6,99 \times 10^{6}$ & $3,81 \times 10^{6}$ & $10,80 \times 10^{6}$ \\
Agustus-2 & $12,97 \times 10^{6}$ & $3,32 \times 10^{6}$ & $16,29 \times 10^{6}$ \\
September-1 & $3,33 \times 10^{6}$ & $3,14 \times 10^{6}$ & $6,47 \times 10^{6}$ \\
September-2 & $8,59 \times 10^{6}$ & $3,85 \times 10^{6}$ & $12,44 \times 10^{6}$ \\
Oktober-1 & $4,27 \times 10^{6}$ & $5,32 \times 10^{6}$ & $9,59 \times 10^{6}$ \\
Oktober-2 & $7,08 \times 10^{6}$ & $5,34 \times 10^{6}$ & $12,42 \times 10^{6}$ \\
November-1 & $28,28 \times 10^{6}$ & $5,67 \times 10^{6}$ & $33,95 \times 10^{6}$ \\
November-2 & $33,63 \times 10^{6}$ & $10,15 \times 10^{6}$ & $43,78 \times 10^{6}$ \\
Desember-1 & $29,10 \times 10^{6}$ & $11,68 \times 10^{6}$ & $40,78 \times 10^{6}$ \\
Desember-2 & $47,68 \times 10^{6}$ & $11,18 \times 10^{6}$ & $58,86 \times 10^{6}$ \\
\hline
\end{tabular}

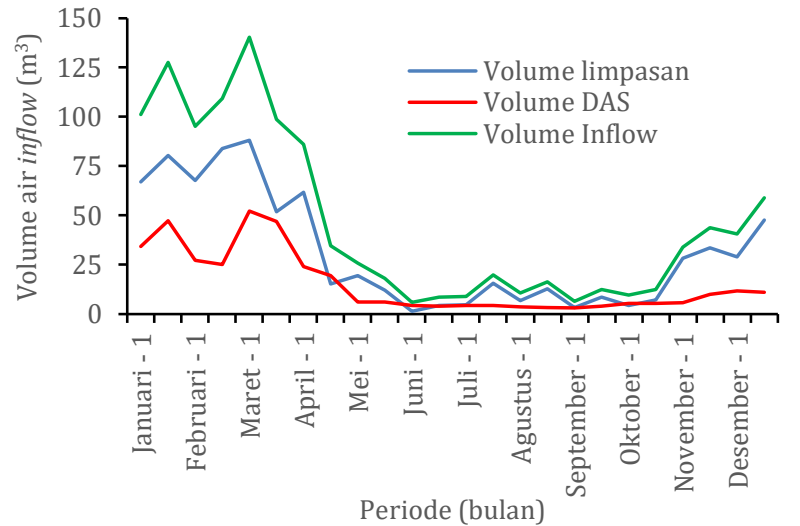

Gambar 1 volume inflow waduk Margatiga

Dari Gambar 1 terlihat bahwa inflow waduk Margatiga, antara limpasan dan debit terukur DAS waduk dalam satu tahun mempunyai pola yang sama. Debit limpasan bendung Argoguruh memberikan 67,10\% dari volume inflow waduk Margatiga sedangkan debit pengukuran terukur di DAS waduk memberikan 32,90\%.

Sedangkan outflow waduk Margatiga diperoleh pola grafik dalam satu tahun untuk simulasi 1 , simulasi 2 dan simulasi 3 juga mempunyai pola yang sama. Debit untuk keperluan suplai irigasi Jabung kiri sebesar $26,71 \%$, suplai irigasi Jabung kanan 55,11\%, suplai air baku 4,35\% dan sisanya untuk pemeliharaan lingkungan hilir 10,95\% dan kehilangan akibat evaporasi $2,84 \%$.

Selanjutnya, dari ketiga simulasi yang ada didapatkan bahwa simulasi 1 dengan neraca outflow untuk tujuan pokok mengaliri irigasi Jabung kiri seluas 5.638,00 ha dengan pola tanam Oktober 2 diperoleh keandalan simulasi 100,00\%. Untuk simulasi 2 dengan neraca outflow untuk tujuan pokok mengaliri irigasi Jabung kiri seluas $5.638,00$ ha dan irigasi Jabung kanan seluas 10.959,00 ha dengan pola tanam Oktober 2 untuk grup kiri dan November 2 untuk grup kanan diperoleh keandalan simulasi 75,00\%. Sedangkan untuk simulasi 3 dengan neraca outflow untuk tujuan pokok mengaliri irigasi Jabung kiri seluas 5.638,00 ha, irigasi Jabung kanan seluas $10.959,00$ ha dengan pola tanam Oktober 2 untuk grup kiri dan November 2 untuk grup kanan dan untuk penyediaan air baku potensial $0,80 \mathrm{~m}^{3} /$ detik diperoleh keandalan simulasi $70,83 \%$.

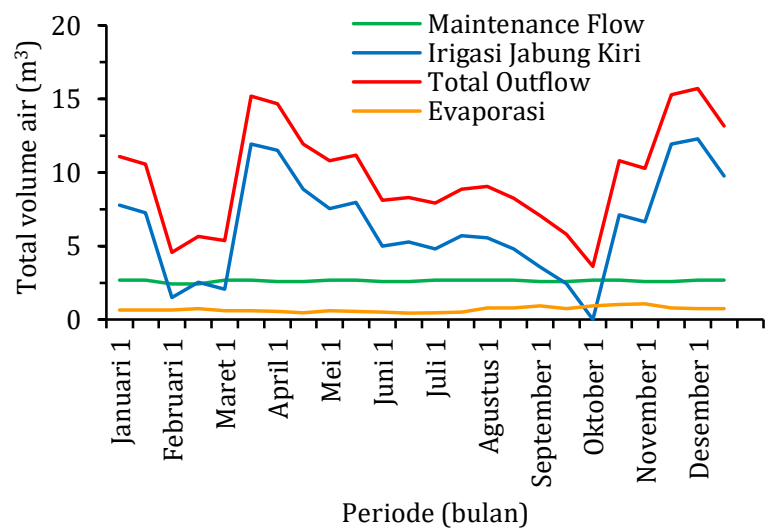

Gambar 2 Volume total outflow simulasi 1 
Rekayasa: Jurnal Ilmiah Fakultas Teknik Universitas Lampung, 24(3), Desember 2020, 62-66

Tabel 2

Volume outflow total waduk dalam tiga skenario simulasi

\begin{tabular}{llll}
\hline Periode & $\begin{array}{l}\text { Simulasi 1 } \\
\left(\mathrm{m}^{3}\right)\end{array}$ & $\begin{array}{l}\text { Simulasi 2 } \\
\left(\mathrm{m}^{3}\right)\end{array}$ & $\begin{array}{l}\text { Simulasi 3 } \\
\left(\mathrm{m}^{3}\right)\end{array}$ \\
\hline Januari-1 & $11,10 \times 10^{6}$ & $26,41 \times 10^{6}$ & $27,48 \times 10^{6}$ \\
Januari-2 & $10,58 \times 10^{6}$ & $24,76 \times 10^{6}$ & $25,85 \times 10^{6}$ \\
Februari-1 & $4,55 \times 10^{6}$ & $7,01 \times 10^{6}$ & $7,97 \times 10^{6}$ \\
Februari-2 & $5,67 \times 10^{6}$ & $17,92 \times 10^{6}$ & $18,89 \times 10^{6}$ \\
Maret-1 & $5,36 \times 10^{6}$ & $20,15 \times 10^{6}$ & $21,22 \times 10^{6}$ \\
Maret-2 & $15,18 \times 10^{6}$ & $38,45 \times 10^{6}$ & $39,52 \times 10^{6}$ \\
April-1 & $14,69 \times 10^{6}$ & $36,37 \times 10^{6}$ & $37,40 \times 10^{6}$ \\
April-2 & $11,93 \times 10^{6}$ & $29,96 \times 10^{6}$ & $31,00 \times 10^{6}$ \\
Mei-1 & $10,79 \times 10^{6}$ & $24,59 \times 10^{6}$ & $25,67 \times 10^{6}$ \\
Mei-2 & $11,16 \times 10^{6}$ & $26,53 \times 10^{6}$ & $27,61 \times 10^{6}$ \\
Juni-1 & $8,10 \times 10^{6}$ & $16,67 \times 10^{6}$ & $17,71 \times 10^{6}$ \\
Juni-2 & $8,31 \times 10^{6}$ & $18,51 \times 10^{6}$ & $19,55 \times 10^{6}$ \\
Juli-1 & $7,94 \times 10^{6}$ & $17,59 \times 10^{6}$ & $18,66 \times 10^{6}$ \\
Juli-2 & $8,87 \times 10^{6}$ & $19,65 \times 10^{6}$ & $20,73 \times 10^{6}$ \\
Agustus-1 & $9,03 \times 10^{6}$ & $19,57 \times 10^{6}$ & $20,65 \times 10^{6}$ \\
Agustus-2 & $8,27 \times 10^{6}$ & $17,29 \times 10^{6}$ & $18,36 \times 10^{6}$ \\
September-1 & $7,09 \times 10^{6}$ & $13,63 \times 10^{6}$ & $14,66 \times 10^{6}$ \\
September-2 & $5,77 \times 10^{6}$ & $10,16 \times 10^{6}$ & $11,19 \times 10^{6}$ \\
Oktober-1 & $3,61 \times 10^{6}$ & $3,61 \times 10^{6}$ & $4,68 \times 10^{6}$ \\
Oktober-2 & $10,79 \times 10^{6}$ & $26,46 \times 10^{6}$ & $27,53 \times 10^{6}$ \\
November-1 & $10,30 \times 10^{6}$ & $24,42 \times 10^{6}$ & $25,46 \times 10^{6}$ \\
November-2 & $15,27 \times 10^{6}$ & $38,85 \times 10^{6}$ & $39,88 \times 10^{6}$ \\
Desember-1 & $15,70 \times 10^{6}$ & $39,20 \times 10^{6}$ & $40,27 \times 10^{6}$ \\
Desember-2 & $13,14 \times 10^{6}$ & $33,93 \times 10^{6}$ & $35,00 \times 10^{6}$ \\
\hline
\end{tabular}

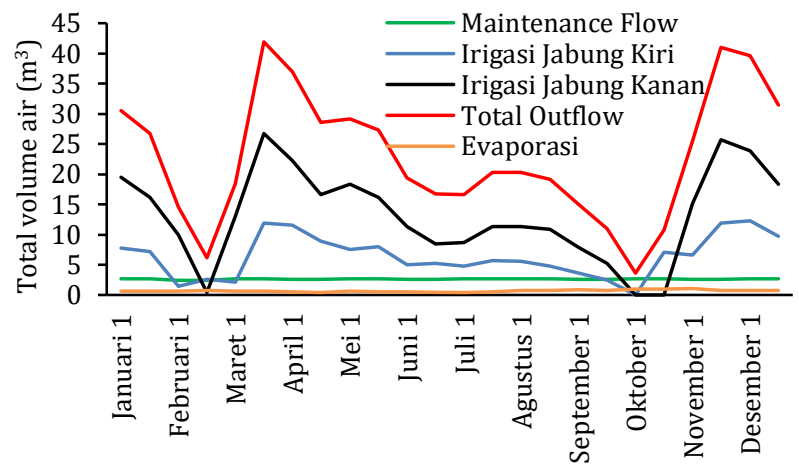

Periode (bulan)

Gambar 3 Volume total outflow simulasi

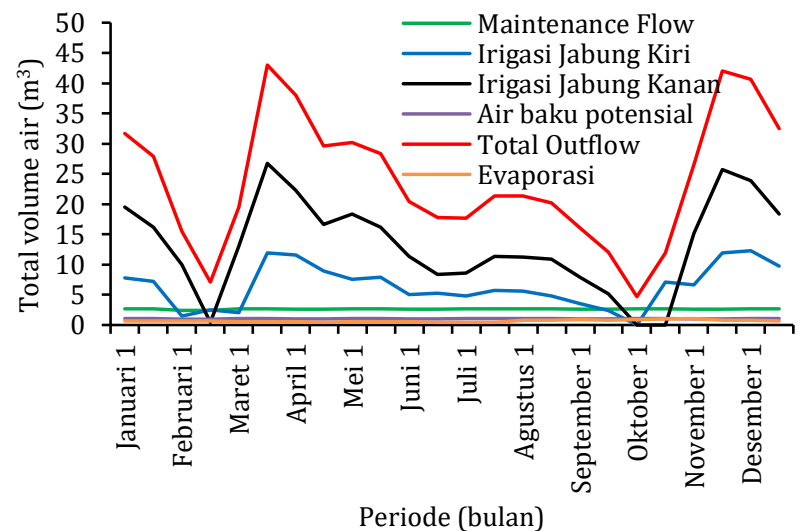

Gambar 4 Volume total outflow simulasi 3
Tabel 3

Volume tampung waduk untuk skenario simulasi 1 (dalam juta $\mathrm{m}^{3}$ )

\begin{tabular}{llllll}
\hline Periode & $\Sigma I$ & $\Sigma O$ & $\Delta S_{0}$ & $\Delta S$ & $\Delta S_{t}$ \\
\hline Januari-1 & 101,27 & 11,10 & 29,59 & 90,17 & 29,59 \\
Januari-2 & 127,75 & 10,58 & 29,59 & 117,17 & 29,59 \\
Februari-1 & 95,08 & 4,55 & 29,59 & 90,53 & 29,59 \\
Februari-2 & 109,14 & 5,67 & 29,59 & 103,47 & 29,59 \\
Maret-1 & 140,40 & 5,36 & 29,59 & 135,04 & 29,59 \\
Maret-2 & 51,80 & 15,18 & 29,59 & 83,58 & 29,59 \\
April-1 & 98,76 & 14,69 & 29,59 & 71,23 & 29,59 \\
April-2 & 34,73 & 11,93 & 29,59 & 22,80 & 29,59 \\
Mei-1 & 25,86 & 10,79 & 29,59 & 15,07 & 29,59 \\
Mei-2 & 18,02 & 11,16 & 29,59 & 6,86 & 29,59 \\
Juni-1 & 5,96 & 8,10 & 29,59 & $-2,13$ & 27,46 \\
Juni-2 & 8,47 & 8,31 & 27,46 & 0,16 & 27,62 \\
Juli-1 & 9,03 & 7,94 & 27,62 & 1,10 & 28,72 \\
Juli-2 & 19,98 & 8,87 & 28,72 & 11,11 & 29,59 \\
Agustus-1 & 10,80 & 9,03 & 29,59 & 1,76 & 29,59 \\
Agustus-2 & 16,29 & 8,27 & 29,59 & 8,02 & 29,59 \\
September-1 & 6,47 & 7,09 & 29,59 & $-0,62$ & 28,97 \\
September-2 & 12,44 & 5,77 & 28,97 & 6,67 & 29,59 \\
Oktober-1 & 9,59 & 3,61 & 29,59 & 5,98 & 29,59 \\
Oktober-2 & 12,42 & 10,79 & 29,59 & 1,62 & 29,59 \\
November-1 & 33,95 & 10,30 & 29,59 & 23,65 & 29,59 \\
November-2 & 43,78 & 15,27 & 29,59 & 28,51 & 29,59 \\
Desember-1 & 40,78 & 15,70 & 29,59 & 25,09 & 29,59 \\
Desember-2 & 58,86 & 13,14 & 29,59 & 45,72 & 29,59 \\
\hline
\end{tabular}

Keterangan: $\Sigma I$ adalah kumulatif inflow, $\Sigma O$ adalah kumulati outflow, $\Delta S_{o}$ adalah volume tampungan awal, $\Delta S$ adalah selisih antara kumulatif inflow dan kumulatif outflow, dan $\Delta S_{t}$ adalah volume tampungan akhir.

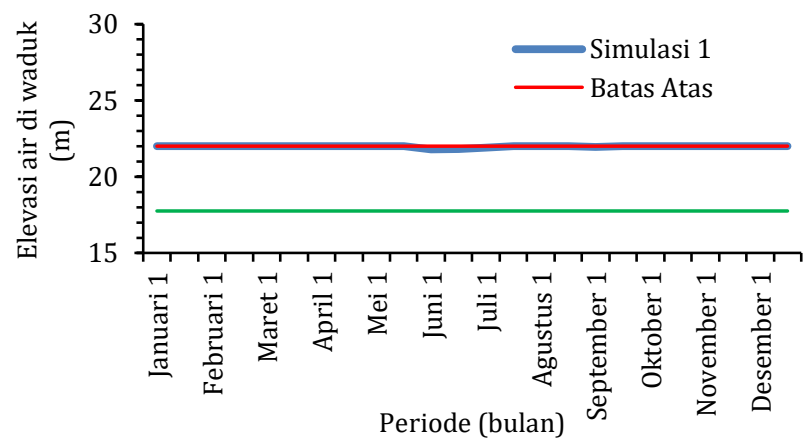

Gambar 5. Elevasi muka air waduk Margatiga simulasi 1

Tabel 4

Volume tampung waduk untuk skenario simulasi 2 (dalam juta $\mathrm{m}^{3}$ )

\begin{tabular}{llllll}
\hline Periode & $\Sigma I$ & $\Sigma O$ & $\Delta S_{o}$ & $\Delta S$ & $\Delta S_{t}$ \\
\hline Januari-1 & 101,27 & 26,41 & 9,59 & 74,86 & 29,59 \\
Januari-2 & 127,75 & 24,76 & 29,59 & 102,97 & 29,59 \\
Februari-1 & 95,08 & 7,01 & 29,59 & 88,08 & 29,59 \\
Februari-2 & 109,14 & 17,92 & 29,59 & 91,22 & 29,59 \\
Maret-1 & 140,40 & 20,15 & 29,59 & 120,25 & 29,59 \\
Maret-2 & 51,80 & 38,45 & 29,59 & 60,32 & 29,59 \\
April-1 & 98,76 & 36,37 & 29,59 & 49,56 & 29,59 \\
April-2 & 34,73 & 29,96 & 29,59 & 4,77 & 29,59 \\
Mei-1 & 25,86 & 24,59 & 29,59 & 1,27 & 29,59 \\
Mei-2 & 18,02 & 26,53 & 29,59 & $-8,51$ & 21,08 \\
Juni-1 & 5,96 & 16,67 & 21,08 & $-10,71$ & 10,37 \\
Juni-2 & 8,47 & 18,51 & 10,37 & $-10,03$ & 3,19 \\
Juli-1 & 9,03 & 17,59 & 3,19 & $-8,55$ & 3,19 \\
Juli-2 & 19,98 & 19,65 & 3,19 & 0,32 & 3,51 \\
Agustus-1 & 10,80 & 19,57 & 3,51 & $-8,78$ & 3,19 \\
Agustus-2 & 16,29 & 17,29 & 3,19 & $-1,00$ & 3,19 \\
September-1 & 6,47 & 13,63 & 3,19 & $-7,16$ & 3,19 \\
September-2 & 12,44 & 10,16 & 3,19 & 2,28 & 5,47 \\
Oktober-1 & 9,59 & 3,61 & 5,47 & 5,98 & 11,45 \\
Oktober-2 & 12,42 & 26,46 & 11,45 & $-14,04$ & 3,19 \\
November-1 & 33,95 & 24,42 & 3,19 & 9,52 & 12,71 \\
November-2 & 43,78 & 38,85 & 12,71 & 4,94 & 17,65 \\
Desember-1 & 40,78 & 39,20 & 17,65 & 1,60 & 19,25 \\
Desember-2 & 58,86 & 33,93 & 19,25 & 24,93 & 29,59 \\
\hline
\end{tabular}




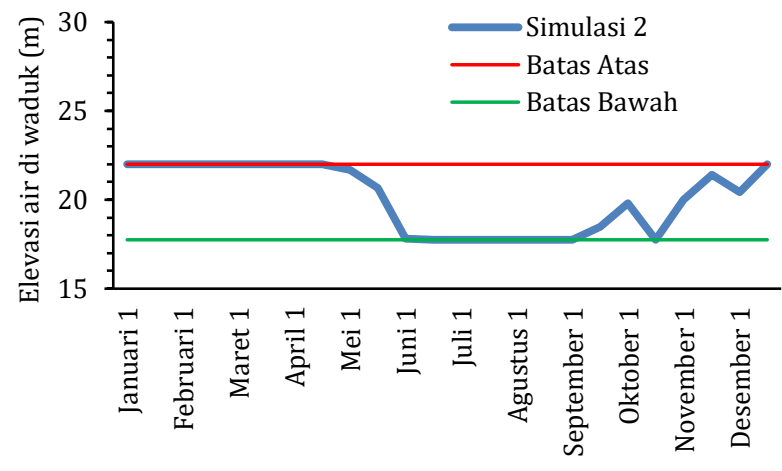

Periode (bulan)

Gambar 6 Elevasi muka air waduk Margatiga simulasi 2

Tabel 5

Volume tampung waduk untuk skenario simulasi 3 (dalam juta $\mathrm{m}^{3}$ )

\begin{tabular}{llllll}
\hline Periode & $\Sigma I$ & $\Sigma O$ & $\Delta S_{0}$ & $\Delta S$ & $\Delta S_{t}$ \\
\hline Januari-1 & 101,27 & 27,48 & 29,59 & 73,79 & 29,59 \\
Januari-2 & 127,75 & 25,85 & 29,59 & 101,90 & 29,59 \\
Februari-1 & 95,08 & 7,97 & 29,59 & 87,11 & 29,59 \\
Februari-2 & 109,14 & 18,89 & 29,59 & 90,25 & 29,59 \\
Maret-1 & 140,40 & 21,22 & 29,59 & 119,18 & 29,59 \\
Maret-2 & 51,80 & 39,52 & 29,59 & 59,25 & 29,59 \\
April-1 & 98,76 & 37,40 & 29,59 & 48,52 & 29,59 \\
April-2 & 34,73 & 31,00 & 29,59 & 3,73 & 29,59 \\
Mei-1 & 25,86 & 25,67 & 29,59 & 0,20 & 29,59 \\
Mei-2 & 18,02 & 27,61 & 29,59 & $-9,59$ & 20,01 \\
Juni-1 & 5,96 & 17,71 & 20,01 & $-11,75$ & 8,26 \\
Juni-2 & 8,47 & 19,55 & 8,26 & $-11,07$ & 3,19 \\
Juli-1 & 9,03 & 18,66 & 3,19 & $-9,62$ & 3,19 \\
Juli-2 & 19,98 & 20,73 & 3,19 & $-0,75$ & 3,19 \\
Agustus-1 & 10,80 & 20,65 & 3,19 & $-9,85$ & 3,19 \\
Agustus-2 & 16,29 & 18,36 & 3,19 & $-2,07$ & 3,19 \\
September-1 & 6,47 & 14,66 & 3,19 & $-8,20$ & 3,19 \\
September-2 & 12,44 & 11,19 & 3,19 & 1,25 & 4,44 \\
Oktober-1 & 9,59 & 4,68 & 4,44 & 4,90 & 9,34 \\
Oktober-2 & 12,42 & 27,53 & 9,34 & $-15,12$ & 3,19 \\
November-1 & 33,95 & 25,46 & 3,19 & 8,49 & 11,68 \\
November-2 & 43,78 & 39,88 & 11,68 & 3,90 & 15,58 \\
Desember-1 & 40,78 & 40,27 & 15,58 & 0,53 & 16,11 \\
Desember-2 & 58,86 & 35,00 & 16,11 & 23,85 & 29,59 \\
\hline
\end{tabular}

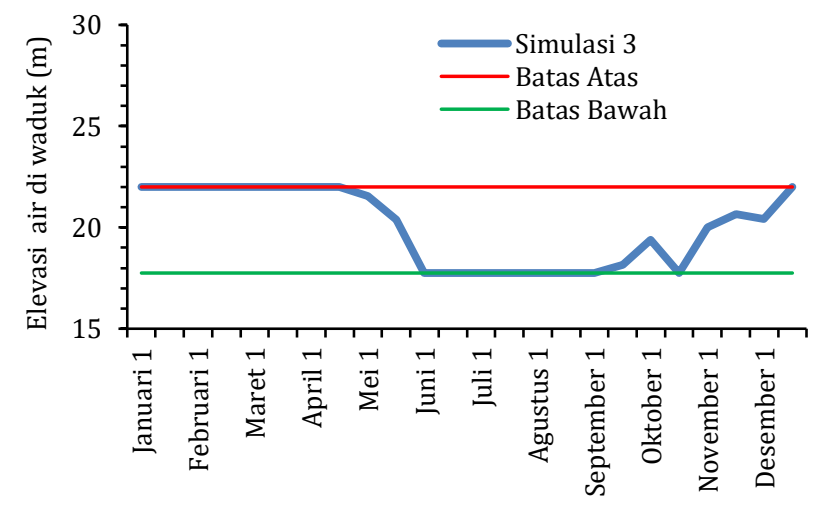

Periode (bulan)

Gambar 7 Elevasi muka air waduk simulasi 3

\section{Kesimpulan}

Waduk Margatiga di Kabupaten Lampung Timur telah di disimulasikan untuk menyelidiki kemampuan beradaptasi operasi bendungan di bawah perubahan iklim. Melalui simulasi bendungan untuk mereproduksi historis tingkat air, ditemukan bahwa aliran keluar akan sangat terbatas pada bulan Mei - Oktober, dan akan sulit untuk mempertahankan pengaturan ketinggian air pada saat bulan-bulan tersebut untuk menjalankan scenario simulasi 3, karena penurunan dan pergeseran aliran masuk. Jika perlu, air keluar bendungan Mei - Oktober harus dikurangi dan disimpan, peraturan ketinggian air harus direvisi, dan kekurangan air waduk di musim panas harus dipertimbangkan dengan hati-hati.

\section{Daftar Pustaka}

[1] Yang, T., Zhang, Q., Chen, Y.D., Tao, X., Xu, C., Chen, X.: A spatial assessment of hydrologic alteration caused by dam construction in the middle and lower Yellow River, China. Hydrol. Process, 22, 2008, 3829-3843.

[2] Mohamed, A.R., Lee, K.T.: Energy for sustainable development in Malaysia: Energy policy and alternative energy. Energy Policy, 34, 2006, 2388-2397.

[3] $H u, L ., Y a n g, X ., L i, Q ., L i, S .:$ Numerical simulation and risk assessment of cascade reservoir dam-break. Water, 12, 6, 2020, 1730.

[4] Cheng, F., Li, W., Castello, L., Murphy, B.R., Xie. S.: Potential effects of dam cascade on fish: lessons from the Yangtze River. Reviews in Fish Biology and Fisheries, 25, 3, 2015, 569 585.

[5] Yi, Y.J., Zhou, Y., Song, J., Zhang, S., Cai, Y., Yang, W., Yang, Z.: The effects of cascade dam construction and operation on riparian vegetation. Advances in Water Resources 131, 2019 , 103206.

[6] Yan, Q.Y, Bi, Y.H., Deng, Y., He, Z., Wu, L.Y., Nostrand, J.D.V., Shi, $Z$.: Impacts of the three Gorges Dam on microbial structure and potential function. Scientific reports, 5, 1, 2015, 1-9.

[7] Poff, N.L., Allan, J.D., Bain, M.B., Karr, J.R., Prestegaard, K.L., Richter, B.D., Sparks, R.E., Stromberg, J.C.: The natural flow regime. A paradigm for river conservation and restoration. BioScience, 47, 1997, 769-784.

[8] Richter, B.D., Baumgartner, J.V., Powell, J., Braun, D.P.: A method for assessing hydrologic alteration within ecosystems. Conserv. Biol. 10, 1996, 1163-1174.

[9] Walker, K.F., Sheldon, F., Puckridge, J.T.: A perspective on dryland river ecosystems. Regul. Rivers Res. Manag. 11, 1995, 85-104.

[10] Lee, J.E, Heo, J.H., Lee, J., Kim, N.W.: Assessment of flood frequency alteration by dam construction via SWAT Simulation. Water, 9, 4, 2017, 264.

[11] Yan, T., Soetopo, W., Heri, S.D.: Evaluasi dan Simulasi Pola Operasi Waduk Tilong di Kabupaten Kupang. Jurnal Teknik Pengairan, 7, 1, 2015, 160-170. 